\title{
DROP SHIPPING DEVELOPMENT UNDER COVID-19 CIRCUMSTANCES AS THE MOST COMMON METHOD OF E-COMMERCE
}

\author{
Pokhylko S., \\ Sumy State University, \\ email: s.pokhylko@finance.sumdu.edu.ua \\ State University \\ email: tetianka.dvorianova@gmail.com \\ Voloshyna E., \\ master student, Department of Finance and Entrepreneurship, \\ Sumy State University, Sumy, \\ email: enessa_krim@yahoo.com
}

PhD in Economics, associate professor, Department of Finance and Entrepreneurship,

Dvorianova T., bachelor student, Department of Finance and Entrepreneurship, Sumy

This article is devoted to analysis of the theoretical foundations and economic essence of drop shipping and the influence of COVID-19 on drop shipping development. The authors conducted bibliometric analysis of the most relevant publications in the Scopus database. The most cited publications on this theme are presented in the paper. Systematization of the scientific background shows that e-commerce exponential growth enhances the impact of drop shipping on developments in business processes. Thus, such an e-commerce drop-shipping supply chain has many advantages. One of them is evident in collaboration with manufacturers and the search for consumers to be supplied for buying their goods and services. Concomitantly, a drop shipper advertises a product to a producer on drop shipper's own websites employing all the marketing strategies and taking orders from the clients. The authors particularly noted the features of inventory management when such a method of e-commerce is used. The reason is that there is no need for a drop shipper to store any products. Hence, the inventory costs are drastically cut. This paper analyzes the main drop shipping tools and their advantages for improving business indicators. The paper embodies the essence of dropshipping from a drop shipper side. The article carries out an analysis of drop shipping types, the most common e-commerce platforms and marketing tools to improve the running the business. This work compares advantages and disadvantages of drop shipping for both a seller and a buyer. Author's algorithm of drop shipping- steps of the drop shipping model functioning - is presented in the work as well as current statistics of the interrelation of the pandemic COVID-19 and a tremendous growth of ecommerce. It was defined that the sales amount among some product categories has soared several times as the pandemic started in the world. Clients preferred to purchase toiletries, medication, food, books, clothes and shoes in online stores. The results of the scientific study are analysis of the major indicators of the drop shipping market and forecast for the future rise in such purchases without a straight participation of producers. Due to the fact that this drop shipping innovative concept provides flexibility and time saving, the clients do not have to visit brickand-stick stores. Which is attractive to clientele and used widely during the lockdown.

Keywords: Drop-shipping, e-commerce, internet marketing, digital economy, e-commerce platforms.

DOI: $10.21272 / 1817-9215.2021 .2-13$

\section{PROBLEM}

The aim of the scientific work is to study the theoretical foundations and economic essence of the analysis financial activity of drop shipping. While a rapid growth of ecommerce, due to the last year's circumstances of the lockdown, the amount of people using drop shipping method also soared either consciously or unconsciously. Thus, it is more safe and less time-consuming, that is why customers choose this way of purchases.

\section{ANALYSIS OF RECENT RESEARCH AND PUBLICATIONS}

The growth of e-commerce is absolutely astonishing and it is not going to slow down any time soon. For a clearer analysis of the terms used and to determine the intersection of the fields of study, we applied the methods of modern bibliometric analysis from the Scopus scientometric database. The key word was «drop shipping». The growing number of articles, which can be demonstrated in Figure 1, indicates that the field of study is in the early growth stage, although the first article was recorded in 2001. The total number of articles in the Scopus database mentioning the term "drop shipping" was 74 (as of the middle of the 2nd quarter of 2021). Some of these articles we used during working on the scientific paper such as Raj Kamalapur (2020) Yuepeng Cheng (2016). 


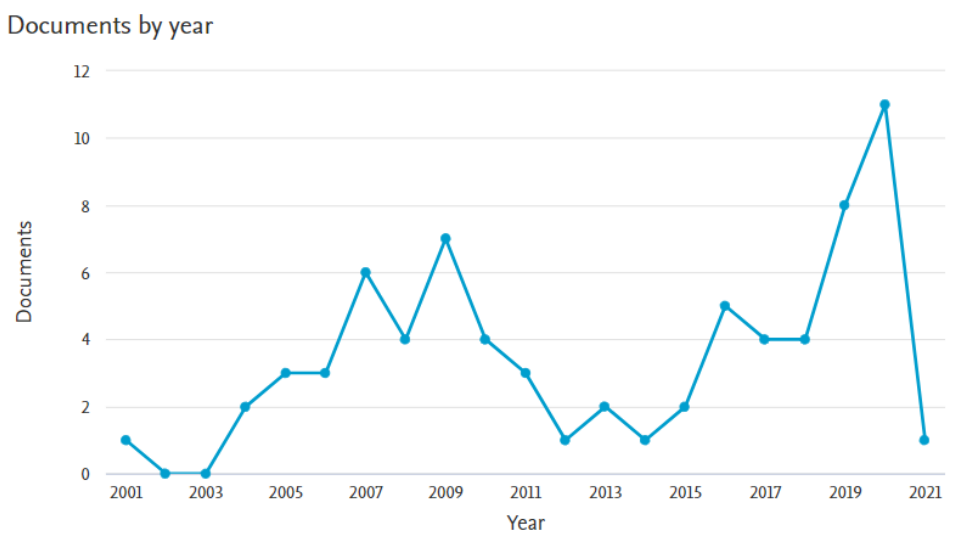

Figure 1 - The trend of academic publications in the field of drop shipping (complied by the authors formed on the Scopus database)

Number of publications has fluctuated within the 20 years period from even zero documents to incredible 11 works in 2020. There was a slight growth in 2004 to 2009 with its peak of 6 works in 2007 and 7 works in 2009. After that, this topic was not been really popular among scientists. Since 2015, the growing attention was certainly seen. As for the year 2021, there is already one conference paper. Based on the results, we can predict a series of new publications will spring up in periodicals.

In the Scopus database, China is the leader of published documents -28 . The second country is United States with its 20 documents. The following countries are Hong Kong - 7 documents, France with 5 and South Korea with only 3 documents (Figure 2). In our scientific work we will dig deeper at the United States situation of this field.

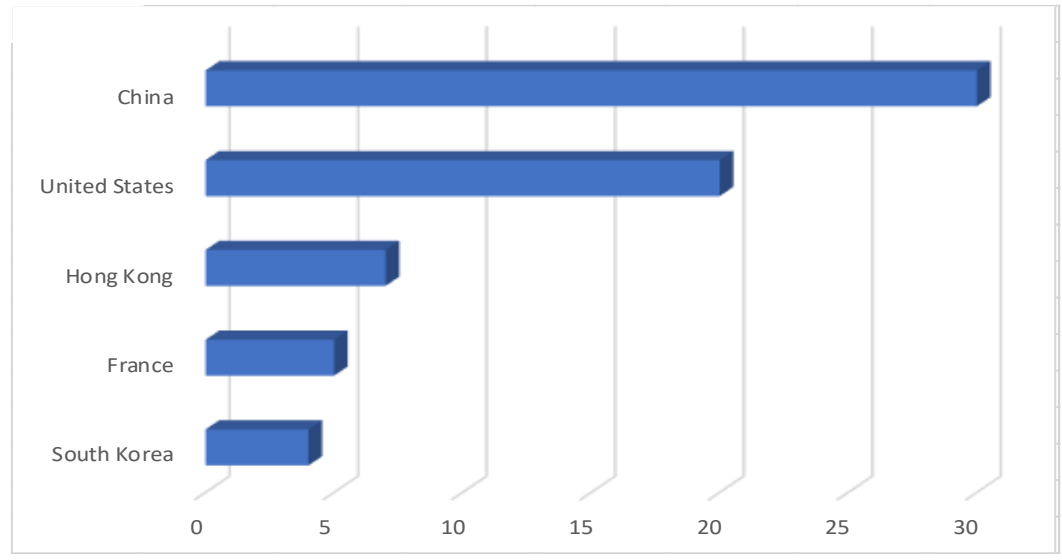

Figure 2 - Documents by TOP-5 countries whose scientists have contributed to the study of drop shipping

(complied by the authors formed on the Scopus database)

The distribution of documents by subject area (Figure 3) varies widely according to all main areas such as Engineering (36 docs); Business, Management and Accounting (28); Decision Sciences (26); Computer Science (25) and no more than 10 in each Mathematics; Social Sciences; Economics, Econometrics and Finance; Materials Science; Energy; Medicine and others. 


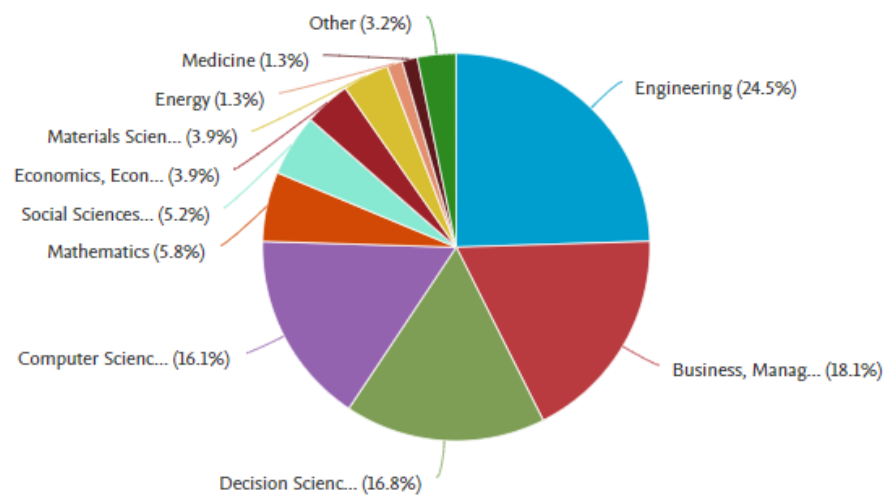

Figure 3 - Separation of documents on drop shipping by areas (complied by the authors formed on the Scopus database)

Figure 4 shows the results of data processing in the VOSviewer software. The size of the circles reflects the density of the terms used. An overlay visualization (Figure 4), network visualization, and density visualization were done for all terms using VOSviewer.

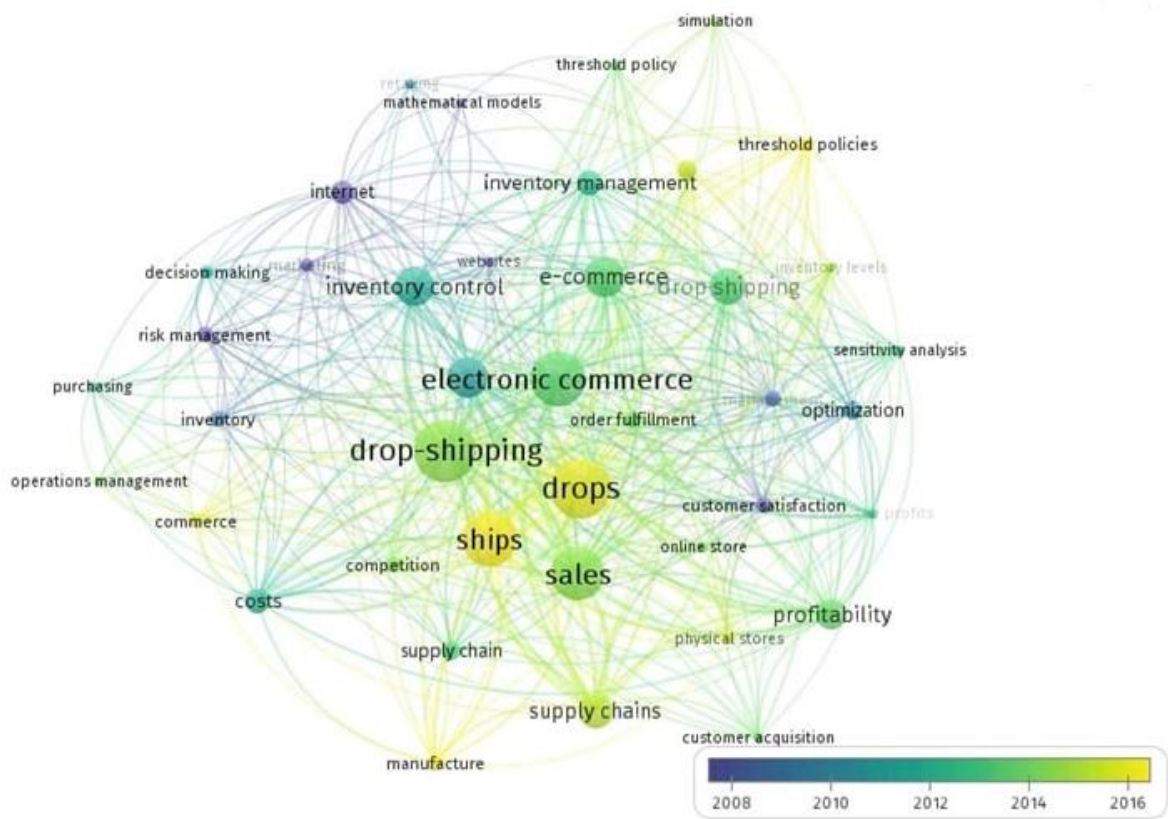

Figure 4 - Network visualization of the most used terms articles of drop shipping (complied by the authors formed on VOSViewer v.1.6.16 using a sample of 74 articles from Scopus Database)

Overall, the attention to this topic is growing, though negligibly (Figure 5). The trend went up starting in 2017 and reached it first peak in August 2020. It took a half a year to reach its highest score 100 points in January 2021. Currently, less people search "drop shipping" but the score is still high -83 points (April 2021). In the last year, the popularity of "drop shipping" wasn't below 50, which means that this topic is definitely popular. To 
sum up, more and more people are getting down to drop shipping and look up for extra information.

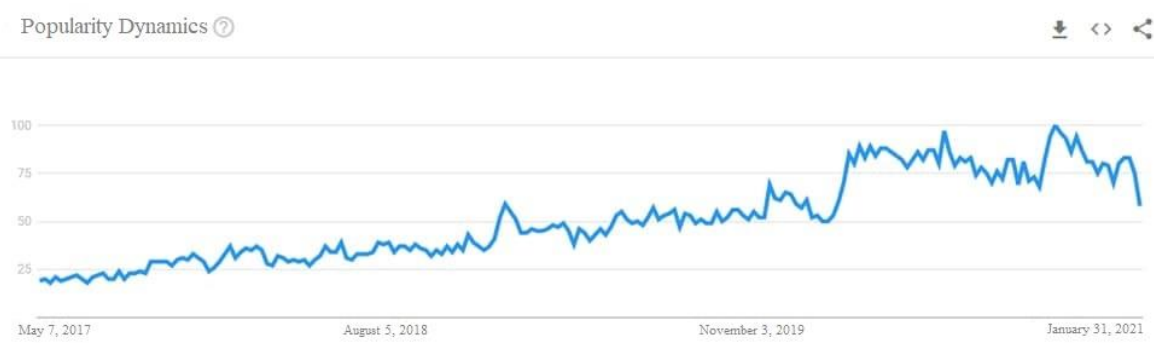

Figure 5 - Popularity Dynamics in a topic "drop shipping” around the world within 2017-2021

(complied by the authors formed on Google Trends Analytics)

Ecommerce is obviously more popular topic among the searchers than dropshipping (Figure 6). In April 2020, there was a sudden interest in both fields. We can assume that it was due to the beginning of the lockdown that started in different times around the world but most certainly in April 2021 the majority of countries were on the strict lockdown. Despite a little decrease in autumn 2020 and a rapid plunge in the following winter, both trends remain stable. On average, the interest in ecommerce is 66 points out of 100, in dropshipping - 22 points. To conclude, ecommerce outweighs dropshipping in three times by popularity.

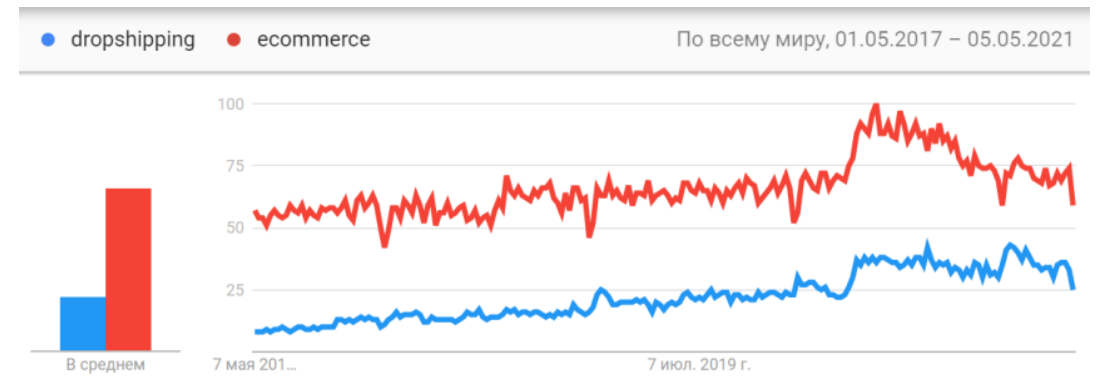

Figure 6-Comparative analysis of popularity in the topics "drop shipping" and "ecommerce" around the world within the last 4 years (complied by the authors formed on Google Trends Analytics)

To sum up, more and more people are getting down to drop shipping and look up for extra information. The COVID-19 pandemic has had a significant impact on all aspects of daily life, including how people shop. This period of isolation and uncertainty has led to massive changes in consumer to buying products online and they prefer to get it near their door using drop shipping. Which eliminated additional chances to caught the virus.

PRESENTATION OF THE MAIN RESEARCH MATERIAL

The essence of drop shipping is to collaborate with a manufacturer and find consumers for their goods and services. The drop-shipper promotes the manufacturer's commodity on their websites, managing all the marketing strategies and takes orders from purchasers. Then the drop-shipper finalizes the transaction and receives payment for the cost of the goods. 
Manufacturers who fall under the following criteria can cooperate with a drop-shipper: manufacturers who do not sell their own goods by themselves; manufacturers who are not engaged in the sale within industry sector. Drop shipping is divided into four types [7].

The drop shipping market was valued at US\$ 162.44 billion in 2019 and is forecasted to reach US\$ 591.77 billion by 207; it is expected to grow at a CAGR of $18.3 \%$ during the forecast period. Consequently, the growth in demand for drop shipping services is mainly driven by the growth of the e-commerce industry. Drop shipping is a wonderful opportunity to enter the entrepreneurship world by only developing online shop and getting registered an account with a supplier.

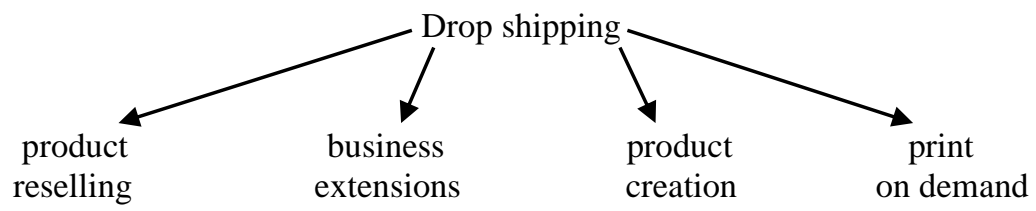

Figure 7 - Types of drop shipping (complied by the authors [1-21])

The most popular e-commerce platforms are Magneto, WooCommerce, Shopify, OpenCart and BigCommerce. (Appendix 2) It doesn't require to store the inventory, no need to spend any money upfront to purchase the products for resale, and not require the additional employees to run the business. When a customer purchases a product from the drop shipping store, he pays resale price. After that the drop-shipper places the order to supplier or manufacturer and pays whole sale price. The last step, the supplier ships the product directly to the buyer [8].

Drop shipping has several points that prove to be beneficial. For Vendors - easy to set up, the cost is affordable, minimum risks, can be run from any place, can offer various products assortment. For Customers - the huge database of products and services available online, comparisons of prices and differences; making orders from anywhere and any place; the items delivered directly to the door. The disadvantages of drop sipping are: low profit margins, highly competitive, no control over supply-chain, legal liability issues, difficult to build a brand.

In order to investigate drop shipping development we design an algorithm of steps to set up drop shipping business [9]. (Scheme 1). In this section, we will look closely at all of them.

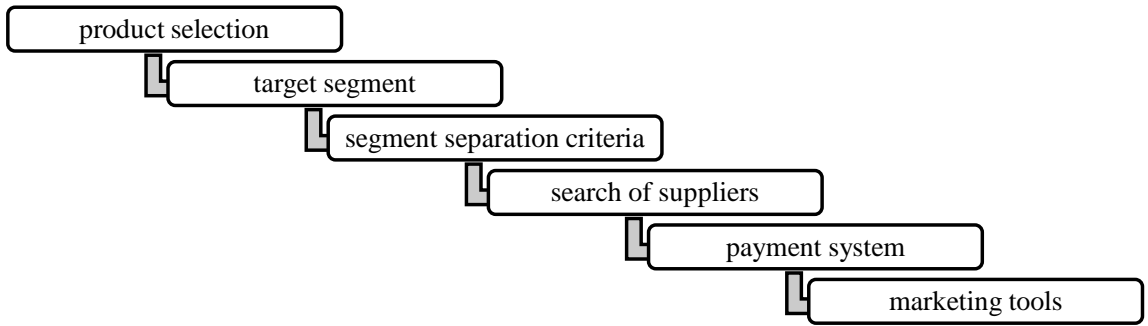

Scheme 1 - The algorithm of drop shipping development (complied by the authors [1-21])

It is believed that product selection is the painful process. Consumers became very demanding. So, it is important to be aware of latest trends. The first step in finding the right product is to conduct research which products are in high demand. Next comes targeting the right niche that helps to increase net income. Niche products or services target a specific customer and product category. For example, a custom product, a retro product, electronics, mobile phone accessories, etc. The next step is to conduct research of the competitor's 
product. It is essential to understand their pricing strategy, marketing methods, target market. In case they have exclusivity with suppliers for the same or identical product, it will be nearly impossible to compete with them. And at last, the price which must be competitive. Buyers will estimate similar products from different drop-shippers and buy the one that is cheaper. There is a need to choose a supplier or close a deal to get the best starting price [10,11]. Drop shipping is mostly based on impulse buying. The success of a business lies in its ability to identify the target segment. The difficulty is that buyers have different preferences and tastes. It is impossible to work with the entire audience of the market, because the "versatility" of the product makes it an average product with average characteristics that no customer completely likes. Therefore, companies strive to find their target audience, which will be most satisfied with the company's product. The concept of a target market helps to use right marketing strategies. Getting known a product, a seller can create the right ad with a high response, select the most attractive packaging or location for the sales department, endowing the product with important properties. The set of characteristics breaks down leads into groups and opens the door for a business to apply a specific marketing strategy that will yield better results than a generalized version for the entire target audience. To define a target market equired to analyze product or service, study competitors, define selection criteria, research competitors. It is advisable to motivate existing traffic for conversions to bring new customers to a store or support the loyalty of previous customers. As for the segment separation criteria, clients can be categorized according to demographic (sex, age, family status, income level, education, employment, occupation, religion, nationality), geographic (region, type of settlement, locality, population density, population, climate) and behavioral characteristics (commitment to the brand, loyalty degree, motives for making a purchase, consumption intensity, readiness to purchase, the volume of purchases, budget, terms of purchase, payment method, decision maker, experience, expertise). A clear definition of customer profile is necessary to create relevant content and communicate with potential customers in the same language [12].

Searching for suppliers and planning cooperation is one of the fundamental questions at the initial stage of a project development. It is beneficial for an entrepreneur to buy products from wholesale distributors. They supply goods at a wholesale price. Suppliers generally fall into three categories: product manufacturers, authorized distributors, and drop-shippers. Examples of companies that offer cooperation on the drop shipping model in Ukraine include the following portals - TM Vilno, Endorphone, Tagtekstil, Opt-toys, Villomi. Examples of overseas wholesalers: All.biz, Esources.co.uk, Goolzi.com, 4wholesaleusa.com, Europages.co.uk, Eurolots.com, Manufacturer.com, etsy.com. Asian Suppliers are aliexpress.com, Taobao.com, 1688.com, alibaba.com. Supplier reliability is an essential component of business success and sustainability.

The main requirement for any online trade is the acceptance of payment for the goods. To do so, it is necessary to connect payment systems that will allow to accept payment from the buyer. Here are the types of the Online Payment Systems: internet banking, online wallet, mobile banking, mobile payment services, mobile operator payments, SMS banking, NFS payments, payment system aggregator [13].

Since the drop shipping is an e-commerce business model, potential customers have various options and choices to buy a product without any restrictions (time, location, currency and et.) Nevertheless, there are marketing tools for the businesses too to create sustain demand, relevance, reputation, competition. All those methods are via internet Social and Digital Marketing such as Facebook, Instagram, LinkedIn, Twitter, Snapchat, YouTube, Pinterest, emailing marketing, content marketing, text messaging and using influencers $[14,15]$.

Drop shipping is a popular business model in the e-commerce industry, now accounting for a third of all e-commerce. The COVID-19 pandemic has affected drop shipping companies and suppliers around the world. About $75 \%$ of companies have been affected by the coronavirus as they are closed and unable to operate. Drop shipping business were drastically affected by this scenario. This means that it may take longer for the product to 
be delivered to the consumer. Online retailers that rely heavily on drop shipping service providers are already facing challenges following the outbreak. Companies are facing a lot of changes due to the virus. China is an important manufacturing center in world trade, and Chinese manufacturers face production disruptions due to factory closures.

Reducing operational costs and marketing expenses and increasing revenues is a top priority for shippers nowadays. One of the ways to save money at the moment is to analyze marketing methods and their results in order to strategically reduce marketing costs. For example, you can temporarily stop add campaigns to save money and reduce potential orders. Additionally, drop-shippers can protect their income by having a small amount of their own inventory that they can use to generate income during a crisis [16].

The coronavirus pandemic has forced brands to drastically change their 2020 ecommerce strategies to cope with changing consumer behavior. Here are some of the latest statistics:

$10 \%$ more time spent on mobile;

$79 \%$ of consumers will continue to spend more conservatively in the coming months;

11\% of advertisers expect COVID-19 to significantly impact their ads spending in Q4 2020;

- $68 \%$ of advertisers expect COVID-19 to impact their ads spending into 2021;

$>62 \%$ of consumers shop online more now than before the pandemic;

$>3.5 \%$ less foot traffic in UK stores the week of October 17th [17].

The COVID-19 pandemic has had a significant impact on all aspects of daily life, including how and what people live. This period of isolation and uncertainty has led to massive changes in consumer buying behavior overnight, from bulk shopping to online shopping. It is estimated that e-commerce will reach US\$ 5 trillion by 2021 . The companies are adapting to online businesses in order to meet the demand and stay afloat. More than 500,000 companies around the world already opened their online stores. Compared to January and February 2020, the 10 major e-Commerce product categories all showed growth rates over of $100 \%$ in April 2020 and over 600\% in the top category. (Table 1)

Table 1 - Wix e-Commerce Growth Report: Top 10 Product Categories during COVID-19 (complied by the authors based on [18])

\begin{tabular}{|l|l|c|}
\hline № & Product Category & Percentage of growth \\
\hline 1 & Food \& Groceries & $605 \%$ \\
\hline 2 & Home \& Décor & $330 \%$ \\
\hline 3 & Pet Care \& Animals & $327 \%$ \\
\hline 4 & Games \& Leisure & $312 \%$ \\
\hline 5 & Clothing \& Apparel & $226 \%$ \\
\hline 6 & Flowers \& Plants & $198 \%$ \\
\hline 7 & Health \& Beauty & $166 \%$ \\
\hline 8 & Books & $151 \%$ \\
\hline 9 & Art \& Crafting & $133 \%$ \\
\hline 10 & Music & $107 \%$ \\
\hline
\end{tabular}

Online shopping becoming more convenient for people as it is safe and less timeconsuming. The chart below shows what are the products and services are the most purchased online in 2020. (Fig. 8) 


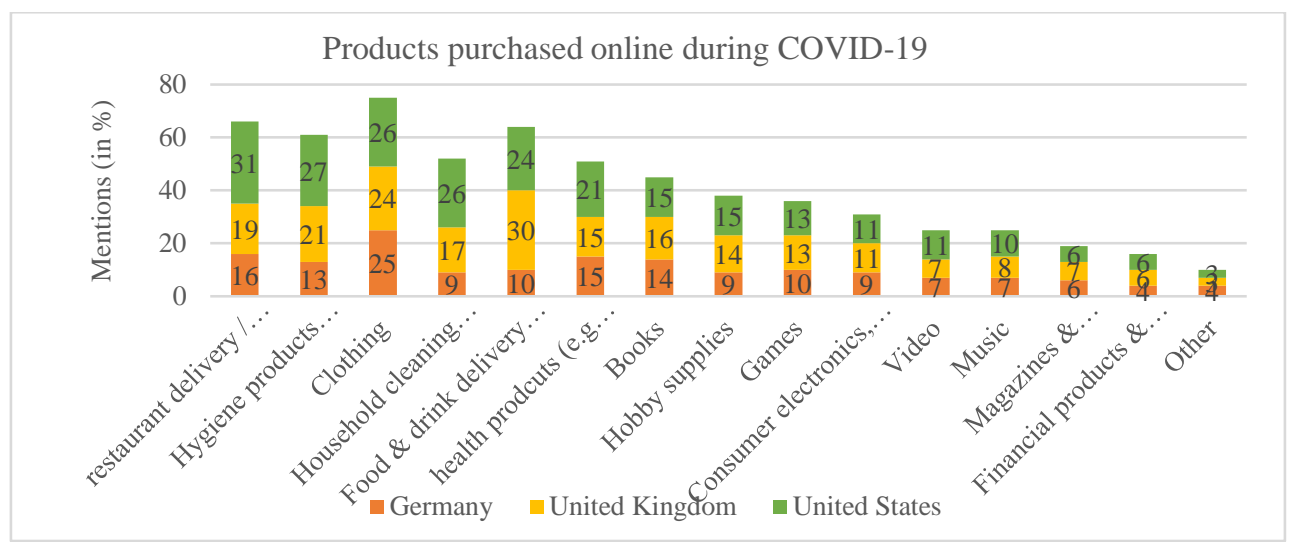

Figure 8-Products deliberately purchased online in 2020 (complied by the authors based on [19])

Since most of the businesses go digital and people are getting used to shop online, there are expectations of growth in online purchase in post-COVID life as well as using drop shipping method. In the chart below shows the predictions of growth.

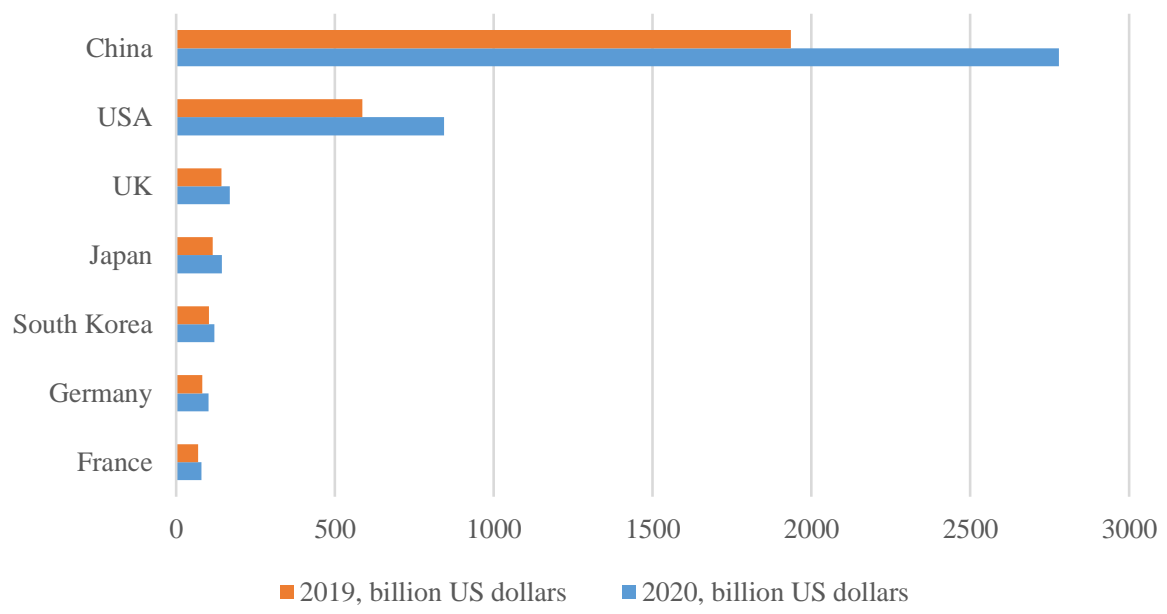

Figure 9 - The Global E-commerce sales by countries by 2019 and 2020 (complied by the authors based on [20])

Accordingly, to Oberlo report China is taking more than half of all global e-commerce sales. It is \$2779,31 trillion e-commerce market represents approximately a half of total global e-commerce sales and exceeds the combined size of the next six in the seven ecommerce markets. (Fig. 9) [21]. It is representable that e-commerce sales grew up significantly in the year 2020 due to the lockdown.

\section{CONCLUSIONS}

Over the past few years, e-commerce has matured into an integral part of the global retail structure. As with many other industries, retail has experienced significant changes since the appearance of the Internet, and with the continued digitalization of modern life and the economy, consumers from almost all countries are now getting the benefits of online transactions. Various reports and statistics show that digital, mobile, and social media have become an essential part of everyday life for people all over the world. The 
number of users has reached a record of 3.8 billion. Approximately $60 \%$ of the world's population is already online, and the latest tendencies Covid -19 indicate that more than half of the world's total population will use social media by the end of this year. Drop shipping had been used by retailers since the 1990 and it is now one of the most popular means of getting stuff buying online, being one of the fast-growing e-commerce methods. This innovative concept of direct delivery brings flexibility and time efficiency because enterprises do not have to physically store inventory or clientele don't have to visit a store. Which is in high demand taking into account the lockdown. To investigate this phenomenon, we carry out bibliometric analysis in this paper.

A general framework of the scientific paper is designed to illustrate the operational processes of drop shipping models, starting from choosing on-line platform to set up an online business, proceeding to finding a target segment and target audience, widening product selection. Search of supplier and imbedding payment systems are also crucially important steps as well as using right marketing strategies and appropriate tools to sell efficiently. For this purpose, we designed the algorithm of drop shipping development. The advantages and weaknesses of drop shipping channel are evaluated for the e-tailor and customers. Analysis of prospects of a drop shipping business was conducted. Developing the new strategies approaching consumers and selling the products, trends assessment of its functionalities was studied including social media tools. To conclude with, it is getting hard to run that business in such a highly competitive market. Although there are still a variety of chances for drop shipping companies to enhance drop shipping businesses and maximize average profit. On condition taking into account the essential elements of the subject which we carried out in scientific papers of modern scientists and practitioners.

Похилько С., Дворянова T., Волошина І., Розвиток дропшиппінгу як найпоширенішого методу електронної комерції. за обставин COVID-19

Стаття присвячена аналізу теоретичних основ та економічної сутності дропшипінгу та впливу пандемії COVID-19 на розвиток дропшипінгу. Проведено бібліометричний аналіз найбільи релевантних публікацій у базі даних Sсориз.Проаналізовано найбільи цитовані публікації за даною тематикою. Систематизація наукового досвіду показує, щчо експоненціальне зростання електронної комериії посилює складову дропшипінгу у розвитку бізнес-прочесів, тому шо у такому ланиюжку поставок електронної комерції є безліч переваг. Одна з них полягає у співпраці з виробниками продукції та пошуку споживачів для їх товарів та послуг. В той час як дроп шипер рекламує товар виробника на свойх веб-сайтах, керуючи всіма маркетинговими стратегіями та приймаючи замовлення від покупців. Особливо вчені звертають увагу на особливості управління запасами за такого методу електронної комериії. Адже зникає необхідність для продавия зберігати будь-яку продукиію. Тобто, витрати на запаси різко скорочуються. У роботі проаналізовано основні інструменти дропшипінгу та їх переваги для покращення показників бізнесу. Розкрито сутність дропшипінгу зі сторони дропшипера. Проведено аналіз типів дропшипінгу, найпопулярніших платформ, маркетингових інструментів для покращення ведення бізнесу. Зіставлено переваги та недоліки дропшипінгу для продавця і для споживача. Представлено авторський алгоритл дропшипінгу - етапи за якими функиіонує модель дропшипінгу. Наведено актуальну статистику взаємозв 'зку пандемї COVID-19 та різкого зростання електронної комериії. Визначено, щчо об'єми продажів деяких категорій продукиії зросли в декілька разів з початком пандемії у світі, клієнти надавали перевагу при покупках в інтернет-магазинах такої продукиії як гігієнічні засоби, ліки, їжа, одяг та взуття, книги. Результатами наукового дослідження є аналіз основних показників ринку дропшипінгу $i$ прогнозування майбутнього зростання таких покупок без прямої участі виробника. Адже ия інноваційна концепція прямої доставки забезпечує гнучкість та економію часу, клієнти не повинні відвідувати магазини. Що користується великим попитом з урахуванням локдауна.

Ключові слова: дропшипінг, електронна комериія, інтернет-маркетинг, циифрова економіка платформи електронної комериії.

\section{REFERENCES}

1.Michelle \& 8 Marketing tips for a successful Dropshipping business. Beeketing - 2018. [Electronic resource] Access mode: https://beeketing.com/blog/drop-shipping-business-marketing/ (English)

2.Maynard H.H., Weidler W.C., Beckman T.N. \& Principles of marketing. New York: Ronald Press - 1927 (English)

3.Chen A. \& It's time for an online store. Business 2 Community - October 24, 2016. [Electronic resource] Access mode: https://www.business2community.com/ecommerce/time-online-store-01687945 (English)

4.Scheel N.T. \& Drop Shipping as a marketing Function. A Handbook of Methods and Policies. Westport (CT): Praeger Publisher - 1990. (English) 
5.The History of Dropshiping: Where Did it All Start? Wholesale TED -[Electronic resource] - Access mode: https://www.wholesaleted.com/the-history-of-

dropshipping/\#: :text=Did\%20you\%20know\%20that\%20dropshipping,advertised\%20a\%20range\%20of\%20items (English)

6.E-commerce: Definition, History, Statistics \& Growth. 2muchcoffee - November, 2018. [Electronic resource] Access mode: https://2muchcoffee.com/blog/ecommerce-definition-history-statistics/ (English)

7.What are the different types of Dropshipping? LeebyKart - 2018. [Electronic mode] - Access Mode: https://leebykart.com/what-are-the-different-types-of-dropshipping/ (English)

8.Isabel V. K. \& Online vs in-store shopping: Where do we buy what? Statista - July 17, 2017. [Electronic resource] - Access mode: https://www.statista.com/chart/10292/shopping-online-and-in-store/ (English)

9. Kamalapur R., Lyth D., \& Impact of Stockout Compensation in E-Commerce Drop-Shipping Supply Chain. Operations and Supply Chain Management - 2020. 13(1) pp.82 - 93 (English)

10.Lee A. \& Comparing Top 5 Ecommerce Platforms For Dropshipping. The Best Is? - January 30, 2019.

[Electronic source] - Access mode: https://www.tigren.com/ecommerce-platforms-for-dropshipping/ (English)

11.Ferreira C. \& How to Find the Best Dropshipping Products to Sell for a Profit. Shopify Blog - January 1, 2020

[Electronic source] - Access mode: https://www.shopify.com/blog/best-dropshipping-products (English)

12. Shmyg A. Target market segment: definition, analysis and selection [Electronic source] - Access mode https://ojok.ru/blog/czelevoj-segment-ryinka-opredelenie,-analiz-i-vyibor (English)

13. Which payment methods can be used with Drop-Shipping [Electronic source] - Access mode https://www.dropshipping.one/en/tutorial/which-payment-methods-can-be-used-with-drop-shipping (English)

14. Cheng Y., Li B., Jiang Y. \& Optimal Choices for the E-Tailer with Inventory Rationing, Hybrid Channel Strategies, and Service Level Constraint under Multiperiod Environments - 2016 (English)

15. Tran T., Sehl K. \& 100 + Social Media Demographics that Matter to Marketers in 2020 - January 15, 2020

[Electronic resource] - Access mode: https://blog.hootsuite.com/social-media-demographics/ (English)

16. The Ecommerce Manager. Dropshipping And The COVID-19 Coronavirus - 06 August, 2020. [Electronic

source] - Access mode: https://www.czechtradeoffices.com/en/cn/news/dropshipping-and-the-covid19coronavirus (English)

17. Toney L., Davis S. \& How Coronavirus (COVID-19) Is Impacting Ecommerce - 17 December, 2020

[Electronic source] - Access mode: https://www.roirevolution.com/blog/2020/10/coronavirus-and-ecommerce/ (English)

18. E-Commerce growth report: Top 10 Products Categories during COVID-19 - May 15, 2020. [Electronic source] - Access mode: https://www.wix.com/blog/ecommerce/2020/05/ecommerce-growth-report-during-covid19 (English)

19. Kunst A. \& Shifting to online purchase because of the COVID-19 pandemic 2020 - July 3, 2020. [Electronic source] - Access mode: https://www.statista.com/statistics/1107859/shifting-to-online-purchases-because-of-thecovid-19-pandemic-by-category/ (English)

20. Ecommerce Sales by Country in 2020. Oberlo - 2021. [Electronic resource] - Access mode: https://www.oberlo.com/statistics/ecommerce-sales-by-country (English)

21. Pokhylko S., Eremenko A. \& Social media platforms use to create and develop business projects. Bulletin of Sumy State University. Series Economy. №3, P.130-139 - 2020. [Electronic resource] - Access mode: https://essuir.sumdu.edu.ua/handle/123456789/81583 (English) 